\title{
Economic Viability and Profitability of Lettuce in Hydroponic System Using Different Effluents
}

\author{
Josilda de França Xavier ${ }^{1}$, Carlos Alberto Vieira de Azevedo², Marcia Rejane de Q. A. Azevedo ${ }^{3}$, \\ Antônio Fernandes Monteiro Filho ${ }^{3} \&$ Carisa Rocha da Silva ${ }^{3}$ \\ ${ }^{1}$ Empresa Estadual de Pesquisa Agropecuária da Paraíba S. A., Estação Experimental de Lagoa Seca, Brazil \\ ${ }^{2}$ Universidade Federal de Campina Grande, Campina Grande, PB, Brazil \\ ${ }^{3}$ Universidade Estadual da Paraíba, Campus-II, Lagoa Seca, PB, Brazil \\ Correspondence: Josilda de França Xavier, Empresa Estadual de Pesquisa Agropecuária da Paraíba S. A., \\ Estação Experimental de Lagoa Seca, Brazil. E-mail: josildaxavier@yahoo.com.br
}

$\begin{array}{lc}\text { Received: April 1, } 2018 & \text { Accepted: May 15, } 2018 \quad \text { Online Published: June 15, } 2018 \\ \text { doi:10.5539/jas.v10n7p342 } & \text { URL: https://doi.org/10.5539/jas.v10n7p342 }\end{array}$

\begin{abstract}
The hydroponic cultivation Lactuca sativa L. can offer producers greater economic profitability, fast financial return due to sanitary and nutritional quality. The objective of this study was to analyze the economic feasibility and profitability indicators of three cultivars of curly lettuce in a hydroponic system using different effluents and well water. The experiment was conducted in a protected environment of the State University of Paraíba-UEPB, Campus-II, in the municipality of Lagoa Seca-Paraíba. Experimental design was in a randomized blocks with plots subdivided in a $7 \times 3$ factorial scheme, with three replications whose factors were 7 hydroponic solutions and three lettuce cultivars. Variables analyzed included gross revenue; gross margin effective and total operating cost; gross margin total cost of production; leveling point effective operating Cost, total production; operating profit and profitability index. The cultivars: Verônica, Vanda and Thais presented the highest gross revenue and profitability index when irrigated with the Furlani solution $\left(\mathrm{S}_{1}\right)$.
\end{abstract}

Keywords: hydroponics, vegetable production, wastewater

\section{Introduction}

The interest in using treated wastewater in irrigation is goal of more recent studies (Bonini et al., 2014), and became an attractive option, since it reduces the contamination by the direct discharge of sewage in water bodies, improving the conditions of potability, allowing the more rational use of water resources, being an alternative source of water available for agriculture (Martínez et al., 2013).

According to Cavalcante, Deon, and Silva (2017), polluted waters can recover their quality and return to aquatic systems using sewage treatment, they can have multiple uses. Therefore, sewage of essentially domestic origin or with similar characteristics, after treatment, which called effluents from sewage treatment plants, can be reused for purposes that require non-potable water, so the treated effluents present a proportion of nutrients that are generally not suitable for the production certain agricultural crops.

Wastewater reuse is an alternative form of pollution control and contributes to increasing water availability in arid and semi-arid regions, with a view to minimizing socio-environmental impacts and when used in agriculture can maximize food production (Araújo, 2012). However, the main salts $\mathrm{Na}^{+}, \mathrm{Ca}^{2+}$ and $\mathrm{Mg}^{2+}$ dissolved in domestic effluents, may hamper agricultural activities, restricted the growth of plants, limiting the withdrawal of water through the modification of osmotic processes, or chemically by metabolic reactions such as caused by toxic constituents (Cavalcante, Deon, \& Silva, 2017).

The lettuce (Lactuca sativa L.) is the larger-scale cultivation by hydroponic cultivation called NFT-Nutrient Film Technique (Potrich, Pinheiro, \& Schmitd, 2012) and stands out in the national scenario of hydroponic crops, being responsible for approximately $80 \%$ of the Brazilian agricultural production of this system (Alves et al., 2011).

The cultivation of lettuce in hydroponic systems is already widely diffused in Brazil, especially by easy, combined with its short cycle Sarmento et al. (2014). According to Cova et al. (2017) who studied lettuce 
cultivation in a hydroponic system and observed that the choice of the hydroponic system and the recirculation interval for lettuce acculturation depends on the quality of the water used in the preparation of the nutrient solution.

The use of nutrient solution without hydroponic cultivation is of fundamental importance, the growth and development of the culture will depend on a suitable formulation (Oliveira et al., 2014). The choice of nutrient solution should be formulated according to the nutritional needs of the species (Furlani et al., 1999). Monteiro Filho et al. (2014) report that in the semi-arid region, lettuce cultivation in the hydroponic system is often made unfeasible by the lack of commercialization of soluble fertilizers, causing the producer to import these inputs from other regions, which significantly increases their costs. According to Santos (2012), the yield of lettuce grown in the soil is approximately 18 tons per hectare, while in hydroponic cultivation the same thing around 46 tons per hectare. Santos (2012) cites that hydroponic cultivation offer producers greater profitability due to product differentiation, sanitary, nutritional quality, visual aspect of hydroponic products can add greater value to the product with the consumer.

The temperature can significantly influence the lettuce crop, changing its production architecture, cycle and resistance to inflorescence (Diamante et al., 2013).

The present work had the objective of analyzing the economic feasibility and profitability indicators of three cultivars of curly lettuce in a hydroponic system using different effluents and well water.

\section{Material and Methods}

The experiment was conducted in a hydroponic system using the laminar nutrient flow technique (NFT), protected environment of the State University of Paraíba, Campus II, in the municipality of Lagoa Seca-PB with the following geographical coordinates: $7^{\circ} 10^{\prime} 15^{\prime \prime} \mathrm{S}, 35^{\circ} 51^{\prime} 14^{\prime \prime} \mathrm{W}$, according to the Köppen-Geige climate classification (Brasil, Ministério da Agricultura, 1971). The experiment was carried out between May and August 2016.

In Figures 1 and 2 the distribution of the hydroponic system is observed, adopting the laminar nutrient flux technique (NFT).

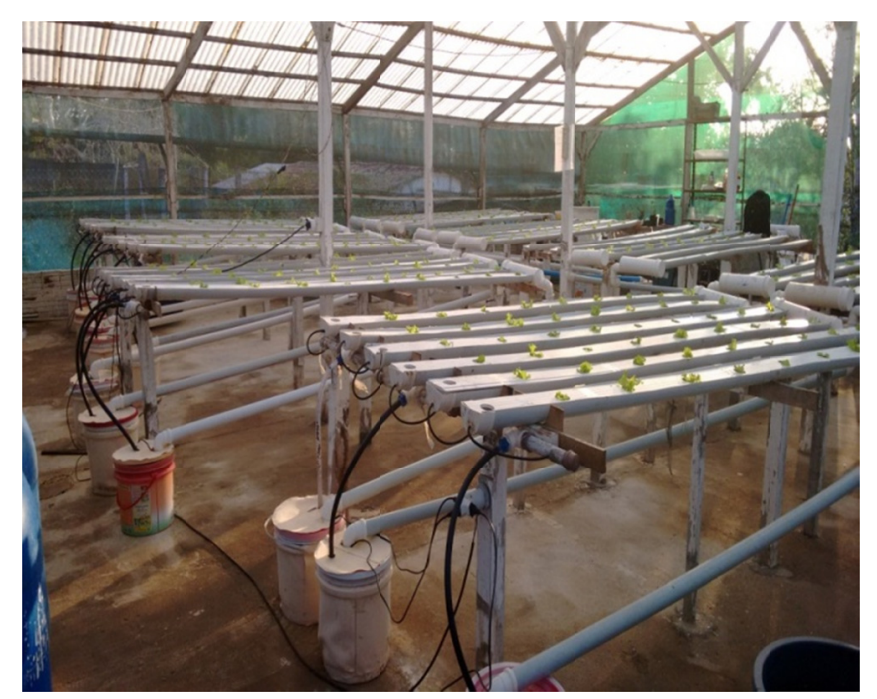

Figure 1. Overview of the experiment with three days of transplanting lettuce cultivars 


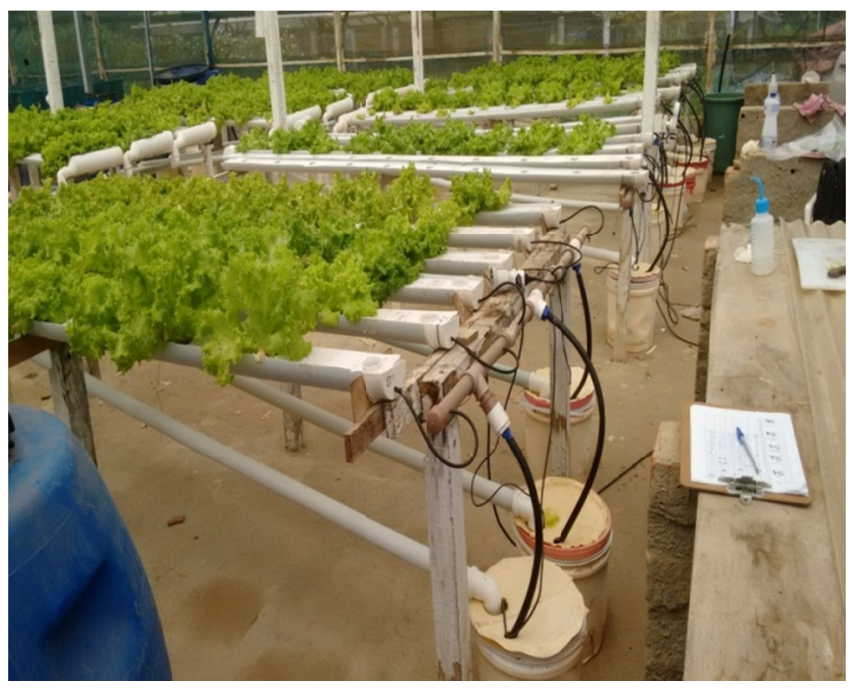

Figure 2. Overview of the experiment with twenty-eight days of transplanting lettuce cultivars

The experimental design was randomized blocks with treatments arranged in subdivided plots, with three replications. The plots consisted of 7 hydroponic solutions with a conductivity of $1.7 \mathrm{dS} \mathrm{m}^{-1}: \mathrm{S}_{1}=$ Furlani solution; $\mathrm{S}_{2}=$ domestic wastewater; $\mathrm{S}_{3}=$ optimized domestic wastewater; $\mathrm{S}_{4}=$ well water; $\mathrm{S}_{5}=$ optimized well water; $S_{6}=$ wastewater solution from the Upflow Anaerobic Sludge Blanket-UASB reactor and $\mathrm{S}_{7}=$ wastewater solution from the optimized UASB reactor and the subplot for three lettuce cultivars from the curly group (Verônica, Vanda and Thais). Each subplot was composed of six plants (two of each cultivar) with spacing of $0.30 \mathrm{~m} \times 0.30 \mathrm{~m}$.

The lettuce seedlings of the cultivars were produced in phenolic foam using a table for germination, sowing a seed pelletized by cavity; after emergence of the seedling (ES), the supply water used in irrigation was gradually replaced by nutrient solutions $(33.33 \%, 66.66 \%$ and $100 \%$ every four days); after 25 days of ES, the seedlings were transplanted to the definitive profiles.

The optimized nutrient solutions were formulated by taking as a reference the nutrient solution of Furlani 1999. For this purpose, the SOLVER tool was used, according to the methodology described by Monteiro Filho et al. (2014).

The water used in the experiment came from rainwater stored in tanks (for solution $\mathrm{S}_{1}$ ), the raw sewage from the city of Lagoa Seca-PB, tubular well water in the rural area of the municipality Lagoa Seca-PB and wastewater from the UASB reactor of the Experimental Station for the Biological Treatment of Sanitary Sewers (EXTRABES) Campina Grande-PB. They were sent for physical-chemical analysis in the Laboratory of Irrigation and Salinity, Agricultural Engineering Academic Unit, Federal University of Campina Grande (LIS/UAEA/UFCG). Table 1 shows the results of the physicochemical characterization of the water used in the hydroponic irrigation, the methodology used (APHA, 1998). 
Table 1. Physical-chemical characterization of waters used in hydroponic irrigation

\begin{tabular}{llll}
\hline Determinations & Well & Raw sewage & Extrabes \\
\hline $\mathrm{pH}$ & 7.7 & 7.4 & 7.2 \\
Electric conductivity $\left(\mathrm{dS} \mathrm{m}^{-1}\right)$ & 0.957 & 2133 & 2.502 \\
Calcium $\left(\mathrm{mmol}_{\mathrm{c}} / \mathrm{L}\right)$ & 3.62 & 3.98 & 5.98 \\
Magnesium $\left(\mathrm{mmol}_{\mathrm{c}} / \mathrm{L}\right)$ & 0.75 & 3.47 & 3.42 \\
Sodium $\left(\mathrm{mmol}_{\mathrm{c}} / \mathrm{L}\right)$ & 3.94 & 10.57 & 15.55 \\
Potassium $\left(\mathrm{mmol}_{\mathrm{c}} / \mathrm{L}\right)$ & 0.38 & 1.26 & 0.01 \\
Chlorides $\left(\mathrm{mmol}_{\mathrm{c}} / \mathrm{L}\right)$ & 6.42 & 9.99 & 23.23 \\
Carbonates $\left(\mathrm{mmol}_{\mathrm{c}} / \mathrm{L}\right)$ & 0.00 & 0.00 & 0.00 \\
Bicarbonate $\left(\mathrm{mmol}_{\mathrm{c}} / \mathrm{L}\right)$ & 1.31 & 10.95 & 3.25 \\
phosphorus $\left(\mathrm{mg} \mathrm{L}^{-1}\right)$ & 4.51 & 29.30 & 4.14 \\
Nitrate $\left(\mathrm{NO}_{3}^{-}\right)\left(\mathrm{mg} \mathrm{L}^{-}\right)$ & 16.73 & 0.00 & 1.03 \\
Ammonia $\left(\mathrm{NH}_{3}\right)(\mathrm{mg} \mathrm{L}$ & 1.27 & 58.6 \\
Sodium adsorption ratio $(\mathrm{SAR})$ & 0.61 & 6.93 & 8.53 \\
Class of water for irrigation & 2.57 & $\mathrm{C}_{3} \mathrm{~S}_{1} \mathrm{~T}_{3}$ & $\mathrm{C}_{3} \mathrm{~S}_{1} \mathrm{~T}_{3}$ \\
\hline
\end{tabular}

The nutrient solutions $\mathrm{S}_{3}, \mathrm{~S}_{5}$ and $\mathrm{S}_{7}$ were prepared according to methodology proposed by Furlani (1995). Once formulated, the organic ingredients were mixed, when necessary, with mineral fertilizers so as to present chemical composition similar to the Furlani solution (Table 2). During the conduction of the experiment the $\mathrm{S}_{1}$ and optimized solutions were calibrated by conducting electrical conductivity (EC) readings and potential of hydrogen $(\mathrm{pH})$ using a portable conductivity meter, plus a peg; the EC was maintained at approximately $1.7 \pm 0.3$ $\mathrm{dS} \mathrm{cm} \mathrm{cm}^{-1}$ and the $\mathrm{pH}$ was between 6.0 and 7.0; independently of the treatments, the nutrient solutions were changed in equidistant periods of 7 days.

Table 2. Quantitative of the fertilizers used in the preparation of mineral nutrient solutions from the physico-chemical characterization of the waters used in hydroponic irrigation

\begin{tabular}{llll}
\hline \multirow{2}{*}{ Ingredients } & \multicolumn{3}{c}{ Quantity of ingredients used to prepare optimized solutions } \\
\cline { 2 - 4 } & $\mathrm{S}_{3}$ & $\mathrm{~S}_{5}$ & $\mathrm{~S}_{7}$ \\
\hline EXTRABES & $199.58 \mathrm{~L}$ & - & - \\
Well water & - & $199.64 \mathrm{~L}$ & - \\
Raw sewage & - & - & $199.64 \mathrm{~L}$ \\
Ammonium sulfate $\left[\left(\mathrm{NH}_{4}\right)_{2} \mathrm{SO}_{4}\right]$ & $23.66 \mathrm{~g}$ & $22.31 \mathrm{~g}$ & $25.09 \mathrm{~g}$ \\
Calcium nitrate $\left[\left(\mathrm{NO}_{3}\right)_{2}\right]$ & $238.24 \mathrm{~g}$ & $237.53 \mathrm{~g}$ & $193.54 \mathrm{~g}$ \\
Potassium nitrate $\left(\mathrm{KNO}_{3}\right)$ & $84.06 \mathrm{~g}$ & $80.95 \mathrm{~g}$ & $121.74 \mathrm{~g}$ \\
Potassium chloride $(\mathrm{KCl})$ & $46.32 \mathrm{~g}$ & $50.04 \mathrm{~g}$ & $0.00 \mathrm{~g}$ \\
Copper Sulfate $\left(\mathrm{CuSO}_{4}\right)$ & $0.04 \mathrm{~g}$ & $0.04 \mathrm{~g}$ & $0.04 \mathrm{~g}$ \\
Zinc sulfate $\left(\mathrm{ZnSO}_{4}\right)$ & $0.11 \mathrm{~g}$ & $0.11 \mathrm{~g}$ & $0.11 \mathrm{~g}$ \\
Manganese Sulfate $\left(\mathrm{MnSo}_{4}\right)$ & $0.49 \mathrm{~g}$ & $0.49 \mathrm{~g}$ & $0.49 \mathrm{~g}$ \\
Magnesium sulphate $\left(\mathrm{MgSO}_{4}\right)$ & $2.19 \mathrm{~g}$ & $4.27 \mathrm{~g}$ & $0.00 \mathrm{~g}$ \\
Ammonium molybdate $\left[\left(\mathrm{NH}_{4}\right)_{6} \mathrm{Mo}_{7} \mathrm{O}_{24}\right]$ & $0.06 \mathrm{~g}$ & $0.06 \mathrm{~g}$ & $0.06 \mathrm{~g}$ \\
Boric acid $\left(\mathrm{H}_{3} \mathrm{BO}_{3}\right)$ & $0.42 \mathrm{~g}$ & $0.42 \mathrm{~g}$ & $0.42 \mathrm{~g}$ \\
Monoammonium phosphate $(\mathrm{MAP})$ & $3.14 \mathrm{~g}$ & $10.43 \mathrm{~g}$ & $5.14 \mathrm{~g}$ \\
Iron sulphate $\left(\mathrm{FeSO}_{4}\right)$ & $12.05 \mathrm{~g}$ & $12.05 \mathrm{~g}$ & $12.05 \mathrm{~g}$ \\
\hline
\end{tabular}

The management of the nutrient solution was carried out daily by replacing the water consumed, monitoring the electrical conductivity $(\mathrm{EC})$ and hydrogenation potential $(\mathrm{pH})$, keeping it close to neutrality, using a solution of $\mathrm{NaOH}$ or HCL $\left(1 \mathrm{~mol} \mathrm{~L}^{-1}\right)$.

For economic feasibility, cost of production analysis was performed according to the methodology suggested by Martin et al. (1998). The following costs were considered in production systems: 
Effective Operational Cost (EOC): are the expenses incurred with manpower, machinery/equipment operations and vehicles and materials consumed throughout the production process;

Total Operating Cost (TOC): is the effective operating cost plus social charges (36\% of the value of the labor expense);

Contribution to Rural Social Security (CSSR) (2.2\% of gross income) and total cost of production (CTP): is the total operating cost plus land leases expenses ( $\mathrm{R} \$ 1.300 .00 /$ year).

In this research was carried out a simulation taking into account an initial investment of $\mathrm{R} \$ 60.000 .00$; acquired by the producer from a financial institution with a charge of $6.5 \%$ p.y. (Banco do Nordeste, 2016). The settlement balance of the outstanding balance was five years, with annual installments in the amount of $\mathrm{R} \$ 14.087 .63$. The final value of the structure was stipulated at $10 \%$ of the initial value and the useful life of the 10 -year system was considered.

Depreciation of greenhouse and equipment: by the straight-line method, the annual depreciation rate was calculated by dividing the initial cost (purchase price or replacement price) minus a presumed final value of scrap by the number of probable years of duration.

$$
\mathrm{D}=\frac{\mathrm{Vi}-\mathrm{Vf}}{\mathrm{N}}
$$

Where, $\mathrm{D}=$ value of depreciation per year; $\mathrm{Vi}=$ initial value, in $\mathrm{R} \$ \mathrm{Vf}=$ final value, in $\mathrm{R} \$ \mathrm{~N}=$ useful life, in years.

The profitability indicators analyzed were as follows:

Gross Revenue (GR):

$$
\text { Gross Revenue }(\mathrm{GR})=\mathrm{P} \times \mathrm{Pu}
$$

Where, $\mathrm{P}=$ production of the activity, and $\mathrm{Pu}=$ unit price of the product of the activity.

Gross Margin of Effective Operating Cost (GMEOC):

$$
\text { GMEOC }(\%)=[(\mathrm{GR}-\mathrm{EOC}) / \mathrm{EOC}] \times 100
$$

Where, $\mathrm{GMEOC}=$ gross margin in relation to $\mathrm{EOC} ; \mathrm{GR}=$ gross revenue and; $\mathrm{EOC}=$ effective operating cost.

Gross Margin Total Operating Cost (GMTOC):

$$
\text { GMTOC }(\%)=[(\mathrm{GR}-\mathrm{TOC}) / \mathrm{TOC}) \times 100
$$

Where, GMTOC $(\%)=$ gross margin in relation to $\mathrm{TOC}$, and TOC $=$ total operational cost.

Gross Margin of Total Cost of Production (GMTCP):

$$
\text { GMTCP }(\%)=[(\text { GR }- \text { TCP }) / \text { TCP }] \times 100
$$

Where, GMTCP $(\%)=$ gross margin in relation to TCP, and TCP $=$ total cost of production.

In addition to these concepts, we used the cost indicators in relation to the product units, called the break-even point, which determines the minimum production required to cover the costs, given the unit sale price for the product. Thus, the following equilibrium points were considered:

Point of Equilibrium $(\mathrm{EOC})=\mathrm{EOC} / \mathrm{Pu}$;

Point of Equilibrium $(\mathrm{TOC})=\mathrm{TOC} / \mathrm{Pu}$;

Point of Equilibrium $(\mathrm{TCP})=\mathrm{TCP} / \mathrm{Pu}$.

Operating Income (OI): The difference between gross revenue and total operating cost (TOC) per year.

$$
\mathrm{OI}=\mathrm{GR}-\mathrm{TOC}
$$

Profitability Index (PI): This indicator shows the ratio of operating profit (OP) to gross revenue (GR), in percent (\%).

$$
\mathrm{PI}=(\mathrm{OI} / \mathrm{GR}) \times 100
$$

For the unit sale value of the lettuce produced in this research, the methodology proposed by Monteiro Filho (2015), where the unit sale value of lettuce was stipulated correlating the average weight of the lettuce produced with those sold in the main supermarkets of the city of Campina Grande, Paraiba, following the following criteria:

Plants weighing less than $75 \mathrm{~g}=\mathrm{R} \$ 0.45$; 
Plants weighing between 76 and $100 \mathrm{~g}=\mathrm{R} \$ 0.75$;

Plants weighing between 101 and $150 \mathrm{~g}=\mathrm{R} \$ 1.00$;

Plants weighing more than $151 \mathrm{~g}=\mathrm{R} \$ 1.25$.

\section{Results and Discussion}

Table 3 shows the average weight of curly lettuce cultivars produced with the mineral solutions $\mathrm{S}_{1}=$ Furlani solution; $\mathrm{S}_{2}=$ domestic wastewater; $\mathrm{S}_{3}=$ optimized domestic wastewater; $\mathrm{S}_{4}=$ well water; $\mathrm{S}_{5}=$ optimized well water; $\mathrm{S}_{6}=$ wastewater solution from UASB reactor and $\mathrm{S}_{7}=$ wastewater solution optimized from the UASB reactor.

Table 3. Average weight of curly lettuce cultivars produced with mineral solutions $\mathrm{S}_{1} ; \mathrm{S}_{2} ; \mathrm{S}_{3} ; \mathrm{S}_{4} ; \mathrm{S}_{5} ; \mathrm{S}_{6}$ and $\mathrm{S}_{7}$

\begin{tabular}{|c|c|c|c|c|c|c|c|}
\hline \multirow{2}{*}{ Cultivars } & \multicolumn{7}{|c|}{ Nutritious solutions } \\
\hline & $\mathrm{S}_{1}$ & $\mathrm{~S}_{2}$ & $\mathrm{~S}_{3}$ & $\mathrm{~S}_{4}$ & $\mathrm{~S}_{5}$ & $\mathrm{~S}_{6}$ & $\mathrm{~S}_{7}$ \\
\hline & \multicolumn{7}{|c|}{ c- } \\
\hline Thaís & 183.66 & 26.50 & 13.58 & 18.16 & 35.83 & 53.50 & 46.83 \\
\hline Vanda & 205.83 & 43.00 & 34.50 & 20.50 & 49.83 & 60.66 & 54.50 \\
\hline Verônica & 184.00 & 15.50 & 13.33 & 36.66 & 35.10 & 40.67 & 13.50 \\
\hline
\end{tabular}

The implementation cost sheets (operation and consumption material), effective operating cost (EOC), total operating cost (TOC) and total cost of production (TCP) of the hydroponic lettuce are detailed in Table 4.

Table 4. Unit values of the items used in the production cost of the hydroponic lettuce as a function of the different nutrient solutions, $S_{1}=$ Furlani solution; $S_{2}=$ domestic wastewater; $S_{3}=$ optimized domestic wastewater; $\mathrm{S}_{4}=$ well water; $\mathrm{S}_{5}=$ optimized well water; $\mathrm{S}_{6}=$ wastewater solution from UASB reactor and $\mathrm{S}_{7}=$ wastewater solution optimized from the UASB reactor

\begin{tabular}{|c|c|c|c|c|c|c|c|}
\hline & $\mathbf{S}_{1}$ & $\mathbf{S}_{2}$ & $\mathbf{S}_{3}$ & $\mathbf{S}_{4}$ & $\mathbf{S}_{5}$ & $S_{6}$ & $\mathbf{S}_{7}$ \\
\hline \multicolumn{8}{|l|}{ Fixed cost $(A)$} \\
\hline Greenhouse & 14087.63 & 14087.63 & 14087.63 & 14087.63 & 14087.63 & 14087.63 & 14087.63 \\
\hline Depreciation & 5.400 .00 & 5.40000 & 5.400 .00 & 5.400 .00 & 5.400 .00 & 5.400 .00 & 5.400 .00 \\
\hline \multicolumn{8}{|l|}{ Variable costs (B) } \\
\hline Seed & 950.00 & 950.00 & 950.00 & 950.00 & 950.00 & 950.00 & 950.00 \\
\hline electricity & 2.200 .00 & 2.200 .00 & 2.200 .00 & 2.200 .00 & 2.200 .00 & 2.200 .00 & 2.200 .00 \\
\hline Foam & 1.500 .00 & 1.500 .00 & $1.500,00$ & 1.500 .00 & 1.500 .00 & 1.500 .00 & 1.500 .00 \\
\hline Maintenance & 2.400 .00 & 2.400 .00 & $2.400,00$ & 2.400 .00 & 2.400 .00 & 2.400 .00 & 2.400 .00 \\
\hline Labor & 5.135 .00 & 5.135 .00 & $5.135,00$ & 5.135 .00 & 5.135 .00 & 5.135 .00 & 5.135 .00 \\
\hline Nutrition solution & 1.172 .06 & 552.24 & $1.677,57$ & 685.12 & 249.07 & 249.20 & 1.028 .03 \\
\hline $\mathrm{EOC}(\mathrm{A}+\mathrm{B})$ & 32.844 .69 & 32.224 .87 & $33.350,20$ & 32.357 .75 & 29.921 .70 & 31.921 .83 & 32.700 .66 \\
\hline \multicolumn{8}{|c|}{ Other Operating Costs $(C)$} \\
\hline Social charges & 3.699 .64 & 3.699 .64 & 3.699 .64 & 3.699 .64 & 3.699 .64 & 3.699 .64 & 3.699 .64 \\
\hline CRSS & 2.750 .00 & 2.200 .00 & 2.750 .00 & 1.540 .00 & 1.540 .00 & 990.00 & 2.156 .00 \\
\hline Business remuneration & 26.100 .00 & 26.100 .00 & 26.100 .00 & 26.100 .00 & 26.100 .00 & 26.100 .00 & 26.100 .00 \\
\hline $\mathrm{TOC}(\mathrm{EOC}+\mathrm{C})$ & 65.394 .34 & 64.224 .51 & 65.899 .85 & 63.697 .39 & 61.261 .35 & 62.711 .47 & 64.656 .30 \\
\hline \multicolumn{8}{|l|}{ Other Fixed Costs (D) } \\
\hline Property for sale (F) & 1.300 .00 & 1.300 .00 & 1.300 .00 & 1.300 & 1.300 .00 & 1.300 .00 & 1.300 .00 \\
\hline $\mathrm{TCP}(\mathrm{A}+\mathrm{B}+\mathrm{C}+\mathrm{D}+\mathrm{F})$ & 66.694 .34 & 65.524 .51 & 67.199 .85 & 64.997 .39 & 62.561 .35 & 64.011 .47 & 65.956 .30 \\
\hline
\end{tabular}

Note. $\mathrm{EOC}=$ Effective Operational Cost; $\mathrm{TOC}=$ Total Operating Cost; $\mathrm{TCP}=$ Total Cost of Production; $\mathrm{CRSS}=$ Contribution to Rural Social Security.

Observing Table 4, it can be observed that the use of $\mathrm{S}_{3}$ solution resulted in the highest effective operating cost (EOC), totaling $\mathrm{R} \$ 33.350 .21$, the use of other solutions provided a percentage reduction of $10.28 ; 3.37 ; 1.95$; 1.95 ; and $1.52 \%$ for solutions $\mathrm{S}_{5}, \mathrm{~S}_{2}, \mathrm{~S}_{6}, \mathrm{~S}_{7}$ and $\mathrm{S}_{1}$ respectively. Monteiro Filho (2015) found in its research 
similar results with mineral solutions compared to organomineral solutions. The importance of the use of the biofertilizer in the preparation of the nutrient solution is due to the fact that it presents diverse chemical composition in macro and micronutrients and, in addition, its manufacture can have a reduced cost, since the majority of the farmers already own the organic ingredients used in its formulation and/or may include other ingredients available on its property at a reduced cost, which will further reduce producer's expenditure (Fernandes et al., 2011).

Also in relation to the reduction of costs provided by the nutrient solution, Cometi et al. (2008), after working with nutrient concentration on hydroponic lettuce growth, concluded that the use of less concentrated solutions and consequently lower fertilizer decreases the cost of production without altering crop productivity.

Table 5 shows the data of the profitability indicators obtained for the cultivars Verônica, Venda, Thaís and for the nutritive solutions. It was observed that the highest profitability index was $47.68 \%$ for all cultivars with the use of the Furlani solution $\left(\mathrm{S}_{1}\right)$.

Table 5. Profitability indexes of Verônica, Vanda and Thaís cultivar in function of the different nutritive solutions, $\mathrm{S}_{1}=$ Furlani, solution; $\mathrm{S}_{2}=$ domestic wastewater; $\mathrm{S}_{3}=$ optimized domestic wastewater; $\mathrm{S}_{4}=$ well water; $\mathrm{S}_{5}=$ optimized well water; $\mathrm{S}_{6}=$ wastewater solution from UASB reactor and $\mathrm{S}_{7}=$ wastewater solution optimized from the UASB reactor

\begin{tabular}{|c|c|c|c|c|c|c|c|c|}
\hline & UND & $\mathbf{S}_{1}$ & $\mathbf{S}_{\mathbf{2}}$ & $\mathbf{S}_{3}$ & $\mathbf{S}_{4}$ & $\mathbf{S}_{5}$ & $S_{6}$ & $\mathbf{S}_{7}$ \\
\hline \multicolumn{9}{|c|}{ Cultivar Verônica } \\
\hline GR & $1.000 \mathrm{R} \$$ & 125.000 & 45.000 & 45.000 & 45.000 & 45.000 & 45.000 & 45.000 \\
\hline GMEOC & $\%$ & 280.58 & 39.64 & 34.93 & 39.07 & 50.39 & 40.97 & 37.61 \\
\hline GMTOC & $\%$ & 91.15 & -28.59 & -29.84 & -28.74 & -25.88 & -28.24 & -29.12 \\
\hline GMTCP & $\%$ & 87.42 & -30.03 & -31.23 & -30.18 & -27.43 & -29.70 & -30.55 \\
\hline LPEOC & $1.000 \mathrm{UND}$ & 26.275 .76 & 71.610 .82 & 74.111 .57 & 71906.11 & 66492.68 & 70937.41 & 72668.14 \\
\hline LPTOC & 1.000 UND & 52.315 .47 & 140.032 .25 & 142.532 .99 & 140327.54 & 134914.10 & 139358.83 & 141089.57 \\
\hline LPTCP & $1.000 \mathrm{UND}$ & 53.355 .47 & 142.921 .13 & 145.421 .88 & 143216.43 & 137802.99 & 142247.72 & 143978.45 \\
\hline O.P. & $1.000 \mathrm{R} \$$ & 59.605 .66 & -18.014 .51 & -19.139 .85 & -18147.39 & -15711.35 & -17711.47 & -18490.30 \\
\hline P.I. & $\%$ & 47.68 & -40.03 & -42.53 & -40.33 & -34.91 & -39.36 & -41.09 \\
\hline \multicolumn{9}{|c|}{ Cultivar Vanda } \\
\hline GR & $1000 \mathrm{R} \$$ & 125.000 & 45.000 & 45.000 & 45.000 & 45.000 & 45.000 & 45.000 \\
\hline GMEOC & $\%$ & 280.58 & 39.64 & 34.93 & 39.07 & 50.39 & 40.97 & 37.61 \\
\hline GMTOC & $\%$ & 91.15 & -28.59 & -29.84 & -28.74 & -25.88 & -28.24 & -29.12 \\
\hline GMTCP & $\%$ & 87.42 & -30.03 & -31.23 & -30.18 & -27.43 & -29.70 & -30.55 \\
\hline LPEOC & $1.000 \mathrm{UND}$ & 26.275 .76 & 71.610 .82 & 74.111 .57 & 71.906 .11 & 66.492 .68 & 70.937 .41 & 72.668 .14 \\
\hline LPTOC & 1.000 UND & 52.315 .47 & 140.032 .25 & 142.532 .99 & 140.327 .54 & 134.914 .10 & 139.358 .83 & 141.089 .57 \\
\hline LPTCP & $1.000 \mathrm{UND}$ & 53.355 .47 & 142.921 .13 & 145.421 .88 & 143.216 .43 & 137.802 .99 & 142.247 .72 & 143.978 .45 \\
\hline O.P. & $1.000 \mathrm{R} \$$ & 59.605 .66 & -18.014 .51 & -19.139 .85 & -18.147 .39 & -15.711 .35 & -17.711 .47 & -18.490 .30 \\
\hline P.I. & $\%$ & 47.68 & -40.03 & -42.53 & -40.33 & -34.91 & -39.36 & -41.09 \\
\hline \multicolumn{9}{|c|}{ Cultivar Thais } \\
\hline GR & $1.000 \mathrm{R} \$$ & 125.000 & 45.000 & 45.000 & 45.000 & 45.000 & 45.000 & 45.000 \\
\hline GMEOC & $\%$ & 280.58 & 39.64 & 34.93 & 39.07 & 50.39 & 40.97 & 37.61 \\
\hline GMTOC & $\%$ & 91.15 & -28.59 & -29.84 & -28.74 & -25.88 & -28.24 & -29.12 \\
\hline GMTCP & $\%$ & 87.42 & -32.53 & -32.53 & -32.53 & -32.53 & -32.53 & -32.53 \\
\hline LPEOC & 1.000 UND & 26.275 .76 & 71610.82 & 74111.57 & 71.906 .11 & 66.492 .68 & 70.937 .41 & 72.668 .14 \\
\hline LPTOC & $1.000 \mathrm{UND}$ & 52.315 .47 & 140032.25 & 142532.99 & 140.327 .54 & 134.914 .10 & 139.358 .83 & 141.089 .57 \\
\hline LPTCP & $1.000 \mathrm{UND}$ & 53.355 .47 & 142921.13 & 145421.88 & 143.216 .43 & 137.802 .99 & 142.247 .72 & 143.978 .45 \\
\hline O.P. & $1.000 \mathrm{R} \$$ & 59.605 .66 & -18014.51 & -19139.85 & -18.147 .39 & -15.711 .35 & -17.711 .47 & -18.490 .30 \\
\hline P.I. & $\%$ & 47.68 & -40.03 & -42.53 & -40.33 & -34.91 & -39.36 & -41.09 \\
\hline
\end{tabular}

Note. GR = Gross Revenue; GMEOC = Gross Margin Effective Operational Cost; GMTOC = Gross Margin Total Operating Cost; GMTCP = Gross Margin Total Cost of Production; LPEOC = Leveling Point Effective Operational Cost; LPTOC $=$ Leveling Point Total Operating Cost; LPTCP = Leveling Point Total Cost of Production; O.P. = operating profit; P.I. = profitability index. 
It is also observed in Table 5 that the highest gross revenue (GR) was found when irrigated with solution $\mathrm{S}_{1}=$ Furlani which reached R\$125.000.00/year.

The increase in profitability is a positive factor for hydroponic activity, the data obtained in this work corroborates with Silva and Schwonka (2006), which studying the economic viability for lettuce production in the hydroponic system concluded that despite the high initial cost, the investment in benefits can be converted in the medium term.

In the investment analysis, a minimum attractiveness rate should be stipulated as the basis for the viability calculations, this is an interest rate that represents the minimum that an investor proposes to earn when making an investment. Dal'Sotto (2013) evaluating the economic feasibility of implementing a hydroponic system to produce lettuce suggested minimum profits equivalent to those provided by fixed income financial investments, such as bank deposit certificates (BDC). These rates tend to fluctuate throughout the year; thus, in this simulation and for practical effect, a minimum attractiveness rate of $12 \%$ p.y. The results obtained in this work show that the use of the mineral solution, independently of the cultivar used, showed a profitability superior to $12 \%$ p.y. In cases where there was economic unfeasibility with negative profitability indexes, since the consumer market would only pay R \$ $0.45 /$ plant, gross revenue would be sufficient to cover actual operating costs and, therefore, would not present a possibility of remuneration to the producer, making it an unfeasible investment.

In general, the prices of conventionally grown vegetables vary throughout the year, because their value is defined as a function of the quality of the product, which in turn is influenced directly by the climatic conditions. The hydroponic cultivation can offer producers greater profitability, because besides a greater control of the environmental conditions in the place of cultivation, there is the differentiation of the product in function of the sanitary and nutritional quality besides the visual aspect of the hydroponic products, adding a greater value to the product with the consumer (Olshe et al., 2001; Souza et al., 2008). According to a survey carried out in Frederico Westphalen, in the state of Rio Grande do Sul per Potrich et al. (2012), 94.4\% of respondents would pay between $\mathrm{R} \$ 0.5$ and $\mathrm{R} \$ 1.00$ more for the hydroponic lettuce unit due to its visual appearance and less contamination by pesticides. Andrade and Silva (2010), hydroponic lettuce to obtain better prices in relation to the conventional one, in their research, carried out in the region of Uberaba, MG, the authors concluded that $61.29 \%$ of consumers are willing to pay $\mathrm{R} \$ 1.00$ more for hydroponic lettuce.

The leveling point of the activity so that no economic loss occurs when there is equality between gross revenue (GR) and total cost of production (TCP). According to Table 6 it can be seen that in the treatments where solutions formulated with residuary water were used, the point of leveling of the total cost of production (LPTCP)

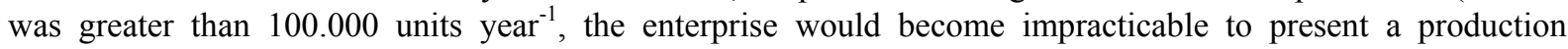
requirement above the projected annual capacity. A similar situation was reported by Geisenhoff et al. (2010), evaluating the economic viability of hydroponic lettuce production in Lavras, MG; in this case the authors proposed a $2.13 \%$ increase in production, from 6.000 to 6.128 in order for the total revenue to cover all the total production costs of the activity.

Table 6 shows that from the fifth year of the activity there was a reduction of production costs with the discharge of the financing and an increase in the profitability index for all cultivars. However, the solution that presented the best profitability index was the solution $\mathrm{S}_{1}(58.95 \%)$ independently of cultivars.

Table 6. Profitability index of the cultivars Thais, Vanda and Verônica, produced without hydroponic system with different nutritive solutions nutritive solutions, $\mathrm{S}_{1}, \mathrm{~S}_{2}, \mathrm{~S}_{3}, \mathrm{~S}_{4}, \mathrm{~S}_{5}, \mathrm{~S}_{6}$ and $\mathrm{S}_{7}$, after the fifth year of implementation of the activity

\begin{tabular}{|c|c|c|c|c|c|c|c|}
\hline \multirow{2}{*}{ Cultivar } & \multicolumn{7}{|c|}{ Nutrition solutions } \\
\hline & $\mathrm{S}_{1}$ & $\mathrm{~S}_{2}$ & $\mathrm{~S}_{3}$ & $\mathrm{~S}_{4}$ & $\mathrm{~S}_{5}$ & $\mathrm{~S}_{6}$ & $\mathrm{~S}_{7}$ \\
\hline & \multicolumn{7}{|c|}{ 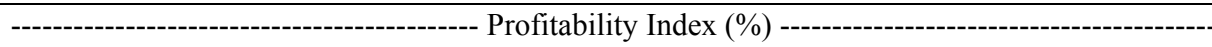 } \\
\hline Thais & 58.95 & -8.73 & -11.23 & -9.02 & -3.61 & -8.05 & -9.78 \\
\hline Vanda & 58.95 & -8.73 & -11.23 & -9.02 & -3.61 & -8.05 & -9.78 \\
\hline Veronica & 58.95 & -8.73 & -11.23 & -9.02 & -3.61 & -8.05 & -9.78 \\
\hline
\end{tabular}

Note. $\mathrm{S}_{1}=$ Furlani solution; $\mathrm{S}_{2}=$ domestic wastewater (raw sewage); $\mathrm{S}_{3}=$ optimized domestic wastewater (raw sewage); $\mathrm{S}_{4}=$ tubular well water; $\mathrm{S}_{5}=$ optimized tubular well brackish water; $\mathrm{S}_{6}=$ wastewater solution from the UASB reactor (Estrabes) and $\mathrm{S}_{7}=$ optimized solution of wastewater from the reactor UASB (Estrabes). 
Increased profitability in the medium term is a positive factor for hydroponic activity, the data obtained in this work corroborate with Silva and Schwonka (2006) who studied the economic viability for lettuce production in the hydroponic system and concluded that despite the high initial cost, the investment in benefits can be converted in the medium term. In another search Monteiro Filho (2015) observed in his work, analyzing the economic viability of lettuce cultivated in hydroponic medium, profitability indexes similar to those found in this research with the use of nutrient solutions formulated with biofertilizers. The lower economic values obtained with uses of solutions prepared with wastewater are related to lower fresh mass production.

\section{Conclusions}

(1) The use of nutritious hydroponic solutions, for lettuce, using wastewater in its constitution, did not present economic feasibility, being necessary more studies for the reuse of effluent in the hydroponic lettuce production.

(2) The cultivars Verônica, Vanda and Thais showed the highest gross revenue when irrigated with the Furlani $\left(\mathrm{S}_{1}\right)$.

(3) All cultivars obtained higher profitability index (P.I.) when irrigated with the Furlani solution $\left(\mathrm{S}_{1}\right)$.

\section{Acknowledgements}

To the National Council of Scientific and Technological Development-CNPq for the grant of scholarship financial support to carry out the research.

\section{References}

Alves, M. S., Soares, T. M., Silva, L. T., Fernandes, P. F., Oliveira, M. L. A., \& Paz, V. P. S. (2011). Estratégias de uso de água salobra na produção de alface em hidroponia NFT. Revista Brasileira de Engenharia agricola e Ambiental, 15, 491-498.

Andrade, M. P. R. de, \& Silva, A. R. P. da. (2010). Marketing do Comportamento do consumidor e da comercialização da alface hidropônica. V CONNEPI. Anais... Maceió.

Araújo, J. C. (2012). Recursos hídricos em regiões semiáridas. In H. R. Gheyi, et al. (Eds.), Recursos hídricos em regiões semiáridas (pp. 29-43). Campina Grande: Instituto Nacional do Semiárido.

APHA (American Public Health Association). (1998). Standard Methods for the Examination-APHA of Water and Wastewater (20th ed.). American Public Health Association, American Water Works Association and Water Environmental Federation, Washington DC.

Bonini, M. A., Sato, L. M., Bastos, R. G., \& Souza, C. F. (2014). Alterações nos atributos químico e físicos de um Latossolo Vermelho irrigado com água residuária e vinhaça. Revista Biociências, 20, 56-63.

Brasil, Ministério da Agricultura. (1971). Equipe de Pedologia e Fertilidade do Solo. Divisão de agrologia-SUDENE, 1971. Levantamento exploratório. Reconhecimento de solos do estado da Paraíba. Boletim Técnico, 15 (p. 670). Rio de Janeiro: Brazil.

Cavalcante, K. L., Deon, M. D., \& Silva, H. K. P. (2017). Estudo das características restritivas dos efluentes das estações de tratamento de esgoto de Petrolina-PE para uso na agricultura irrigada. Revista Brasileira de Agricultura Irrigada, 11(2), 1331-1338.

Cometti, N. N., Matias, G. C. S., Zonta, E, Mary, W., \& Fernandes, M. S. (2008). Compostos nitrogenados e açúcares solúveis em tecidos de alface orgânica, hidropônica e convencional. Horticultura Brasileira, 22(4), 748-753.

Cova, A. M. W., Freitas, F. T. O. de, Viana, P. C., Rafael. M. R. S., Azevedo Neto, A. D. De, \& Soares, T. M. (2017). Content of inorganic solutes in lettuce grown with brackish water in different hydroponic systems. Revista Brasileira de Engenharia Agrícola e Ambiental, 21(3), 150-155.

Dal'sotto, T. C. (2013). Estudo de viabilidade econômica para implantação de um sistema de cultivo hidropônico em uma propriedade rural no oeste do Paraná. (p. 67, Dissertação Mestrado, Universidade Tecnológica Federal do Paraná, Brazil).

Diamante, M. S., Seabra Jr. S., Inagaki, A. M., Silva, M. B., \& Dallacort, R. (2013). Produção e resistência ao pendoamento de alfaces tipo lisa cultivadas sob diferentes ambientes. Revista Ciência Agronômica, 44(1), 133-140.

Fernandes J. D., Monteiro Filho A. F., Chaves L. H. G., Gonçalves C., \& Cruz M. P. (2011). Formulação de biofertilizante utilizando a ferramenta Solver do Microsoft Office. Revista Verde, 6(4), 101-105. 
Ferreira, D. F. (2000). Análise estatística por meio do SISVAR (Sistema para Análise de Variância) para Windows versão 4.0. Reunião Anual da Região Brasileira da Sociedade Internacional De Biometria, 45 (pp. 255-258). São Carlos. Anais... São Carlos: UFSCar.

Furlani, P. R., Bolonhezi, D., Silveira, L. C. P., \& Faquin, V. (1999). Nutrição mineral de hortaliças, preparo e manejo de soluções nutritivas. Informe Agropecuário, 20(200/201), 90-98.

Geisenhoff, L. O., Pereira, G. M., Faria, L. C., Lima Júnior, J. A., Costa, G. G., \& Gatto, R. F. (2010). Viabilidade econômica da produção de alface hidropônica em Lavras-MG. Revista Agrarian, 2(6), 61-69.

Martin, N. B., Serra, R., Oliveira, M. D. M., Ângelo, J. A., \& Okawa, H. (1998). Sistema integrado de custos agropecuários-CUSTAGRI. Informações Econômicas, 28(1), 7-28.

Martínez, S., Suay, R., Moreno, J., \& Segura, M. L. (2013). Reuse of tertiary municipal wastewater effluent for irrigation of Cucumis melo L. Irrigation Science, 31, 661-672.

Monteiro Filho, A. F. (2015). Análise técnica e econômica da alface crespa cultivada hidroponicamente com soluções minerais e organominerais otimizadas (p. 165, Tese de Doutorado, Universidade Federal de Campina Grande, Brazil).

Monteiro Filho, A. F., Pereira, G. L., Azevedo, M. R. Q. de A., Fernandes, J. D., \& Azevedo, C. A. V. de. (2014). Cultivo hidropônico de cultivares de alface em soluções nutritivas organominerais otimizadas com a ferramenta Solver. Revista Brasileira de Engenharia Agrícola e Ambiental, 18, 417-424.

Oliveira, L. L. P., Farias, W. C., Linhares, P. S. F., Melo, M. R. S., Cavalcante, J. J., \& Dombronski, J. L. D. (2014). Análise de diferentes dosagens de solução nutritiva no cultivo de mudas de alface americana (Lactuca sativa L.). Revista Agropecuária Científica no Semiárido, 10(2), 14-17.

Olshe, S., Dourado Neto, D., Manfron, P. A., \& Santos, O. S. (2001). Qualidade de cultivares de alface produzidos em hidroponia. Scientia Agricola, 58(1), 181-185.

Potrich, A. C. G., Pinheiro, R. R., \& Schmitd, D. (2012). Alface hidropônica como alternativa de produção de alimentos de forma sustentável. Enciclopédia Biosfera, 8(15), 36.

Sarmento, J. D. A., Morais P. L. D., Almeida, M. L. B., Sousa Neto, O. N. De, \& Dias, N. da S. (2014). Qualidade e conservação da alface cultivada com rejeito da dessalinização. Revista Caatinga, 27, 90-97.

Santos, O. S. (2012). Cultivo hidropônico (p. 264). Santa Maria: UFSM.

Silva, E. T. da, \& Schwonka, F. (2006). Viabilidade econômica para a produção de alface no sistema hidropônico em Colombo, Região Metropolitana de Curitiba, PR. Scientia Agraria, 2(1-2), 111-116.

Souza, I. R. S., Arbage, A. P., Neumann, P. S., Diesel, J. M. F. V., Silveira, P. R., Silva, A., ... Lisboa, R. S. (2008). Comportamento de compra dos consumidores de frutas, legumes e verduras na região central do Rio Grande do Sul. Ciência Rural, 38(32), 511-517.

\section{Copyrights}

Copyright for this article is retained by the author (s), with first publication rights granted to the journal.

This is an open-access article distributed under the terms and conditions of the Creative Commons Attribution license (http://creativecommons.org/licenses/by/4.0/). 